University of Nebraska - Lincoln

DigitalCommons@University of Nebraska - Lincoln

New Diets for Production of House Flies and Stable Flies (Diptera:

Muscidae) in the Laboratory

Jerome Hogsette

USDA-ARS, Jerry.Hogsette@ars.usda.gov

Follow this and additional works at: https://digitalcommons.unl.edu/usdaarsfacpub

Part of the Agricultural Science Commons

Hogsette, Jerome, "New Diets for Production of House Flies and Stable Flies (Diptera: Muscidae) in the Laboratory" (1992). Publications from USDA-ARS / UNL Faculty. 1005.

https://digitalcommons.unl.edu/usdaarsfacpub/1005

This Article is brought to you for free and open access by the U.S. Department of Agriculture: Agricultural Research Service, Lincoln, Nebraska at DigitalCommons@University of Nebraska - Lincoln. It has been accepted for inclusion in Publications from USDA-ARS / UNL Faculty by an authorized administrator of DigitalCommons@University of Nebraska - Lincoln. 


\title{
New Diets for Production of House Flies and Stable Flies (Diptera: Muscidae) in the Laboratory
}

\author{
JEROME A. HOGSETTE \\ USDA-ARS, Medical and Veterinary Entomology Research Laboratory, \\ P.O. Box 14565, Gainesville, FL 32604
}

\begin{abstract}
J. Econ. Entomol. 85(6): 2291-2294 (1992)
ABSTRACT A diet for rearing the house fly, Musca domestica (L.), was developed from feed constituents available on a year-round basis in Gainesville, FL. The diet, called the Gainesville House Fly Diet, performed as well or better than the Chemical Specialties Manufacturers' Association fly larval medium (CSMA) and can be mixed, bagged, and delivered by a local feed mill within $3 \mathrm{~d}$. By adding pelleted peanut hulls $1: 1$ by volume, the house fly diet becomes suitable for rearing the stable fly, Stomoxys calcitrans (L.). Use of these diets and the economics involved are discussed further.
\end{abstract}

KEY WORDS Musca domestica, Stomoxys calcitrans, larval diets

LARVAL DIETS FOR the production of muscoid flies in the laboratory evolved from the use of natural media commonly exploited by the flies (e.g., animal manures) (Glaser 1924; Parr 1959) to the development of artificial diets, many of which have been based on Chemical Specialties Manufacturers' Association larval medium (CSMA, Ralston Purina, St. Louis, MO) or some of its components (Wilkes et al. 1948; McGregor \& Dreiss 1955; Goodhue \& Cantrel 1958; Keiding \& Arevad 1964; Bailey et al. 1975; Bridges \& Spates 1983; Pickens \& Lorenzen 1983; Morgan 1986). In most cases, ingredients for larval diets were measured separately and mixed as needed.

At the USDA Medical and Veterinary Entomology Research Laboratory in Gainesville, FL, 5 liters of dry medium moistened with water are added to a larval tray and seeded with $\approx 30,000$ muscoid fly eggs; five to ten trays of house flies, Musca domestica L., and two to three trays of stable flies, Stomoxys calcitrans (L.), are set up daily. Approximately $4.5 \mathrm{t}$ of dry larval diet are used annually. At this level of production, mixing three or four components of a diet in the laboratory results in diet variability, production of an inordinate amount of dust, and extra work for colony personnel. Additional problems arise when components are not available on a yearround basis.

Published house fly and stable fly diets were analyzed using Morrison (1961). House fly diets were found to have a wide protein range (10-

This article reports the results of research only. Mention of a commercial or proprietary product does not constitute an endorsement or a recommendation for its use by USDA.
$25 \%$ ), but a comparatively narrow fiber range (15-20\%). Fiber in stable fly diets generally exceeded 25\% (McGregor \& Dreiss 1955, Christmas 1970, Bridges \& Spates 1983). When CSMA is used for stable fly production, it is usually combined with a high-fiber material, presumably to slow the fermentation rate. In some locations, preferred materials such as pelleted or baled sugar cane bagasse and pelleted bermuda grass are either no longer produced or are seasonal and difficult to obtain. Materials such as oat hulls or vermiculite float and cannot be used if pupae are separated from the growth medium by flotation.

The purpose of this study was to develop a basic house fly larval medium similar to CSMA, but from components available locally on a year-round basis, and which could be mixed at a local feed mill, bagged, and delivered in 0.9-t lots, as needed. The basic diet medium would be mixed with a high-fiber component, also available locally, for the production of stable flies.

\section{Materials and Methods}

Brewers' dried grains were omitted as a potential constituent for the test diets because they are not available commercially except in certain locations, none of which is close enough to Gainesville to make the product economically feasible to use. Wheat bran, successfully used by Morgan (1986) to dilute CSMA, was chosen as the major constituent. Alfalfa meal, a CSMA component that is usually available throughout the United States, was included in the list of potential con- 
Table 1. Composition and selected nutritional factors of CSMA and four test diets used to rear house flies

\begin{tabular}{|c|c|c|c|c|c|}
\hline & Diet 1 & Diet 2 & Diet 3 & Diet 4 & CSMA \\
\hline Constituent & & & Amount (\%) & & \\
\hline Alfalfa meal & 50 & 20 & 30 & 20 & 27 \\
\hline Wheat bran & 35 & 50 & 50 & 60 & 33 \\
\hline Corn meal & - & 30 & 20 & 15 & - \\
\hline Meat + bone meal & 15 & 一 & - & - & - \\
\hline Brewers' yeast & - & - & - & 5 & - \\
\hline Brewers' dried grains & - & - & - & - & 40 \\
\hline Factor & & & Composition (\%) & & \\
\hline Protein & 22.08 & 14.47 & 15.33 & 15.45 & 19.0 \\
\hline Fat & 3.44 & 3.92 & 3.78 & 3.89 & 3.0 \\
\hline Fiber & 15.86 & 10.43 & 12.62 & 11.52 & 20.0 \\
\hline Ash & 12.35 & 5.46 & 6.34 & 6.01 & 8.0 \\
\hline
\end{tabular}

Values are extracted from Morrison (1961).

stituents. Because brewers' dried grains were excluded, fine corn meal was used to help initiate the fermentation process. Meat and bone meal and brewers' yeast were considered as sources of additional protein. Composition of the test diets and CSMA and selected nutritional factors of each are shown in Table 1.

In the first trial, diets were measured into larval rearing trays ( 50 by 40 by $10 \mathrm{~cm}$ ) (Morgan 1986), moistened with water at a ratio of $1: 1$ by volume, and seeded with $\approx 30,000$ house fly eggs $<6 \mathrm{~h}$ old. Each diet was replicated twice, except for the CSMA diet, which was not replicated. The diets with developing larvae were held at $26.7^{\circ} \mathrm{C}$ and $60 \% \mathrm{RH}$. After $7 \mathrm{~d}$, pupae were separated from diets by flotation and air dried. Total and mean pupal weight, percentage adult eclosion, and percentage yield of pupae and adults were measured.

In the second trial, only diets 2 and 3 (Table 1 ) were compared with CSMA. The diets were prepared and maintained as described above. To check for short-term adverse effects of test diets on fecundity and adult eclosion, the percentage hatch of $F_{1}$ eggs and percentage eclosion of $F_{1}$ adults were measured and compared.

Pelleted peanut hulls, a high-fiber (40-60\%), relatively inert material in good supply yearround in area feed stores, were added to diet 3
(Table 1 ) at a ratio of $1: 1$ by volume. This decreased the protein to $\approx 10 \%$ and increased the fiber to $\approx 30 \%$. Diet 3 plus pelleted peanut hulls was compared with CSMA plus pelleted peanut hulls ( $1: 1$ by volume). Diets were measured into standard larval rearing trays, moistened with water at a ratio of 5 parts diet: 6 parts $\mathrm{H}_{2} \mathrm{O}$ by volume, and seeded with $\approx 30,000$ stable fly eggs $<6$ $\mathrm{h}$ old. These diets also were held at $26.7^{\circ} \mathrm{C}$ and $60 \%$ RH. Pupae were separated from diets by flotation, and pupal weight, percentage adult eclosion, and percentage yield of pupae and adults were measured.

Where appropriate, data were analyzed with GLM Procedures, and Tukey's studentized range test (SAS Institute 1985) was used for separation of means. Unless otherwise stated, $P=$ 0.05 .

\section{Results and Discussion}

Mean weights of house fly pupae produced in all five diets ranged from 14.0 to $16.3 \mathrm{mg}$ (Table 2 ), and there were no significant differences between the weights of pupae produced in either CSMA or diets 2 and 3. Pupal yield, adult eclosion, and adult yield were $>80,90$, and $78 \%$, respectively, for all diets. Pupae produced in diet 1 weighed significantly less than those pro-

Table 2. Production of house flies with four test diets and CSMA fly larval medium

\begin{tabular}{lcccccccc}
\hline \hline Diet $^{a}$ & $\begin{array}{c}\text { Eggs per } \\
\text { tray }(n)\end{array}$ & $\begin{array}{c}\text { Total } \\
\text { pupal wt } \\
(\mathrm{g})\end{array}$ & $\begin{array}{c}\text { Mean pupal } \\
\text { wt }( \pm \mathrm{SD}) \\
(\mathrm{mg}) n=80\end{array}$ & $\begin{array}{c}\text { Est. total } \\
\text { pupae }\end{array}$ & $\begin{array}{c}\text { \% Yield } \\
\text { (pupae) }\end{array}$ & $\begin{array}{c}\text { Eclosion } \\
(n)\end{array}$ & $\begin{array}{c}\text { Total }^{b} \\
\text { adults }\end{array}$ & $\begin{array}{c}\% \text { Yield } \\
(\text { adults) }\end{array}$ \\
\hline CSMA & $30,000(1)$ & 420 & $14.0(0.75) \mathrm{ab}$ & 30,000 & 100.0 & $97.4(194)$ & 29,220 & 97.4 \\
Diet 1 & $30,000(2)$ & 645 & $12.2(0.35) \mathrm{c}$ & 52,869 & 88.1 & $98.5(194)$ & 52,076 & 86.8 \\
Diet 2 & $30,000(2)$ & 797 & $15.1(0.23) \mathrm{ab}$ & 52,782 & 88.0 & $92.3(208)$ & 48,718 & 81.2 \\
Diet 3 & $30,000(2)$ & 829 & $15.4(0.85) \mathrm{a}$ & 53,831 & 89.7 & $95.9(195)$ & 51,624 & 86.0 \\
Diet 4 & $30,000(2)$ & 796 & $16.3(0.22) \mathrm{a}$ & 48,834 & 81.4 & $96.4(193)$ & 47,076 & 78.5 \\
\hline
\end{tabular}

Means followed by the same letter are not significantly different $(P=0.05$; Tukey's studentized range test [SAS Institute 1985])

a CSMA, alfalfa meal $27 \%$, wheat bran $33 \%$, brewers' dried grains $40 \%$; Diet 1 , alfalfa meal $50 \%$, wheat bran $35 \%$, meat \& bone meal $15 \%$; Diet 2, alfalfa meal $20 \%$, wheat bran $50 \%$, corn meal $30 \%$; Diet 3, alfalfa meal $30 \%$, wheat bran $50 \%$, corn meal $20 \%$; Diet 4 , alfalfa meal $20 \%$, wheat bran $60 \%$, corn meal $15 \%$, brewer's yeast $5 \%$.

$b \%$ Yield (pupae $)=($ total pupae $\div$ total eggs $) \times 100$

$c \%$ Yield (adults) $=($ total adults $\div$ total eggs $) \times 100$ 
Table 3. Production of house flies with test diets 2 and 3 and CSMA fly larval medium

\begin{tabular}{|c|c|c|c|c|c|c|c|c|}
\hline Diet $^{2}$ & $\begin{array}{c}\text { Eggs per } \\
\text { tray }(n)\end{array}$ & $\begin{array}{c}\text { Total } \\
\text { pupal wt } \\
\text { (g) }\end{array}$ & $\begin{array}{c}\text { Mean pupal } \\
\text { wt }( \pm \mathrm{SD}) \\
(\mathrm{mg}) n=80\end{array}$ & $\begin{array}{l}\text { Est. total } \\
\text { pupae }\end{array}$ & $\begin{array}{c}\text { \% Yield } \\
\text { (pupae) }\end{array}$ & $\begin{array}{c}\% \\
\text { Eclosion } \\
(n)\end{array}$ & $\begin{array}{c}\text { Total } \\
\text { adults }\end{array}$ & $\begin{array}{c}\text { \% Yield }{ }^{c} \\
\text { (adults) }\end{array}$ \\
\hline CSMA & $30,000(1)$ & 262 & $9.9(0.37) \mathrm{b}$ & 26,465 & 88.2 & $95.5(198)$ & 25,274 & 84.3 \\
\hline Diet 2 & $30,000(2)$ & 803 & $15.0(0.50) \mathrm{a}$ & 53,533 & 89.2 & $97.2(398)$ & 52,034 & 86.7 \\
\hline Diet 3 & $30,000(2)$ & 848 & $15.8(0.43) \mathrm{a}$ & 53,671 & 89.5 & $99.0(405)$ & 53,134 & 88.6 \\
\hline
\end{tabular}

Means followed by the same letter are not significantly different ( $P=0.05$; Tukey's studentized range test [SAS Institute 1985]).

"CSMA, alfalfa meal $27 \%$, wheat bran $33 \%$, brewers' dried grains $40 \%$; Diet 2 , alfalfa meal $20 \%$, wheat bran $50 \%$, corn meal $30 \%$; Diet 3 , alfalfa meal $30 \%$, wheat bran $50 \%$, corn meal $20 \%$.

i $\%$ Yield (pupae) $=$ (total pupae $\div$ total eggs $) \times 100$

c \% Yield (adults) $=($ total adults $\div$ total eggs $) \times 100$

duced in the other four diets. Pupal yields were greater than expected from CSMA and diets $1-4$, but mean pupal weights were less than expected from CSMA and diet 1 (Table 2). Pupae produced in diet 1 weighed less than the 15- to 18-mg pupae produced by Morgan (1986), who used the same rearing technique but a different diet. The lighter pupae may have resulted from the use of meat and bone meal, which increased the ash content in diet 1 to $12.35 \%$ (Table 1). The diet tended to compact when water was added. Because of the lighter pupal weights, diet 1 was eliminated from further testing.

In diet 4, pupae were numerically heavier, but yields of pupae and adults were numerically lower than those of the other 4 diets. Because it was desirable to maximize both pupal weight (size), and pupal and adult yields, diet 4 was eliminated from further testing in favor of diets 2 and 3.

When CSMA and diets 2 and 3 were compared, the mean weight of pupae produced in CSMA was significantly lower than the mean weights of those produced in the two test diets (Table 3). The reason for this discrepancy is unknown and inconsequential, because results were otherwise similar for all three diets (Table 3 ). Percentage hatch of $F_{1}$ eggs and percentage eclosion of $F_{1}$ adult flies ranged from 95.5 to $97.5 \%$, and from 79.5 to $87.0 \%$, respectively. $\mathrm{Pu}$ pal yields from all three diets exceeded those of Pickens \& Lorenzen (1983) and Morgan (1986), and it was evident that either diet 2 or 3 would be a suitable substitute for CSMA. Diet 3 was chosen ultimately as the Gainesville House Fly Diet because diet 2, which contained a greater amount of corn meal, tended to sour and support fungal growth.

When pelleted peanut hulls were added to both CSMA and diet 3 for rearing stable flies, the mean pupal weight was $\approx 10 \mathrm{mg}$ (Table 4). This compared favorably with results reported by Bailey et al. (1975), who produced pupae with an average weight of $\approx 10 \mathrm{mg}$; however, some of the sugar cane bagasse diets tested by Bridges \& Spates (1983) produced pupae that weighed $14 \mathrm{mg}$. Differences in pupal weights may have been caused by differences in dietary constituents. Also, my tests were performed during the winter months when maximum size of stable fly pupae can be difficult to maintain even though rearing conditions remain constant year round.

Diet 3 plus pelleted peanut hulls produced a pupal yield that was similar to those reported by Bailey et al. (1975) (56-75\%) and Bridges \& Spates (1983) (42-58\%) but higher than that produced by CSMA plus pelleted peanut hulls (Table 4). Adult eclosion and adult yield produced with diet 3 plus pelleted peanut hulls were higher than those produced with CSMA plus pelleted peanut hulls (Table 4) and only slightly lower than those reported by Bailey et al. (1975) (95\% and 52\%, respectively) and Bridges \& Spates (1983) (95\% and $48 \%$, respectively). As a result of these tests, diet 3 plus pelleted peanut hulls was selected to be the Gainesville Stable

Table 4. Production of stable flies with test diet 3 and CSMA fly larval medium, both mixed with an equal volume of pelleted peanut hulls

\begin{tabular}{lcccccccc}
\hline \hline Diet & $\begin{array}{c}\text { Eggs per } \\
\text { tray }(n)\end{array}$ & $\begin{array}{c}\text { Total } \\
\text { pupal wt } \\
(\mathrm{g})\end{array}$ & $\begin{array}{c}\text { Mean pupal } \\
\mathrm{wt}( \pm \mathrm{SD}) \\
(\mathrm{mg}) n=80\end{array}$ & $\begin{array}{c}\text { Est. total } \\
\text { pupae }\end{array}$ & $\begin{array}{c}\text { \% Yield } \\
(\text { pupae })\end{array}$ & $\begin{array}{c}\text { Eclosion } \\
(n)\end{array}$ & $\begin{array}{c}\text { Total } \\
\text { adults }\end{array}$ & $\begin{array}{c}\% \text { Yield } \\
\text { (adults) }\end{array}$ \\
\hline $\begin{array}{c}\text { CSMA + pelleted } \\
\text { peanut hulls }\end{array}$ & $30,000(1)$ & 115 & $10.6(0.40)$ & 10,849 & 36.2 & $88.9(773)$ & 9,645 & 32.2 \\
$\begin{array}{l}\text { Diet 3 + pelleted } \\
\text { peanut hulls }\end{array}$ & $30,000(1)$ & 153 & $10.2(0.21)$ & 15,000 & 50.0 & $89.7(778)$ & 13,455 & 44.9 \\
\hline
\end{tabular}

a CS.MA, alfalfa meal $27 \%$, wheat bran 33\%, brewers' dried grains $40 \%$; Diet 3, alfalfa meal $30 \%$, wheat bran $50 \%$, corn meal $20 \%$.

$b \%$ Yield (pupae) $=($ total pupae $\div$ total eggs $) \times 100$

$c \%$ Yield (adults) $=($ total adults $\div$ total eggs $) \times 100$ 
Fly Diet, the standard diet for rearing stable flies at our laboratory.

House fly and stable fly pupae produced in our colony in CSMA-based diets at $26.7^{\circ} \mathrm{C}$ and $60 \%$ RH (normal colony conditions) are separated from the media (diets) $7 \mathrm{~d}$ after eggs are added. This 7-d cycle was not altered by any of the house fly or stable fly test diets. Materials used in the test diets allowed for easy separation of pupae by flotation. To prepare the Gainesville House Fly Diet, the diet is measured and mixed with water and the eggs are added. To prepare the Gainesville Stable Fly Diet, the Gainesville House Fly Diet is mixed dry with pelleted peanut hulls. After water is added, the diet is allowed to stand for $\approx 30 \mathrm{~min}$ before further processing to ensure adequate breakdown of pellets. The diet is mixed again, and the eggs are added.

Maintenance of our house fly and stable fly colonies required an annual CSMA purchase of $\approx \$ 5,000.00$, or $\approx \$ 25.00$ per 23 -kg bag. Shipments made through a local feed store were delivered to our laboratory, and our personnel assisted with the unloading process. Quality of the CSMA varied with warehouse storage time. The Gainesville House Fly Diet (diet 3) can be ordered

from a local feed mill in 0.91-t lots, mixed, bagged in 23-kg bags, delivered, and unloaded (by feed mill personnel) in our storage facility within $3 \mathrm{~d}$. The cost is $\approx \$ 1,500.00 / \mathrm{yr}$, or $\approx \$ 7.50$ per $23-\mathrm{kg}$ bag. This constitutes an annual savings of $\$ 3,500.00$, or $\$ 18.00$ per bag. Pelleted peanut hulls are purchased separately and mixed $1: 1$ by volume with the Gainesville House Fly Diet at the laboratory. The average cost is $\$ 3.00$ for a 23-kg bag. A 23-kg bag of the Gainesville House Fly Diet plus pelleted peanut hulls $(1: 1)$ would cost $\approx \$ 5.25$.

Although these diets were formulated with constituents available year round in the Gainesville area, similar diets could be formulated for use in any location. Wheat bran, alfalfa meal, and corn meal are fairly common materials, but suitable substitutes could be found for these if necessary. The same is true for pelleted peanut hulls. Volume may be a problem if the colony size is small. Many feed mills will not mix lots of $<0.91 \mathrm{t}$, however, smaller feed mills and university feed mills might be more accommodating.

\section{Acknowledgment}

I thank J. Morgan, USDA-ARS, Gainesville, FL, for his technical assistance in this study.

\section{References Cited}

Bailey, D. L., T. L. Whitfield \& G. C. LaBrecque. 1975. Laboratory biology and techniques for mass producing the stable fly, Stomoxys calcitrans (L.) (Diptera: Muscidae). J. Med. Entomol. 12: 189-193.

Bridges, A. C. \& G. E. Spates. 1983. Larval medium for the stable fly, Stomoxys calcitrans (L.). Southwest. Entomol. 8: 6-10.

Christmas, P. E. 1970. Laboratory rearing of the biting fly Stomoxys calcitrans (Diptera: Muscidae). N.Z. Entomol. 4: 45-49.

Glaser, R. W. 1924. Rearing flies for experimental purposes with biological notes. J. Econ. Entomol. 17: 486-496.

Goodhue, L. D. \& K. E. Cantrel. 1958. The use of vermiculite in medium for stable fly larvae. I. Econ. Entomol. 51: 250.

Keiding, J. \& K. Arevad. 1964. Procedure and equipment for rearing a large number of housefly strains. Bull. W. H. O. 31: 527-528.

McGregor, W. S. \& J. M. Dreiss. 1955. Rearing stable flies in the laboratory. J. Econ. Entomol. 48: 327-328.

Morgan, P. P. 1986. Mass culturing microhymenopteran pupal parasites (Hymenoptera: Pteromalidae) of filth breeding flies, pp. 77-87. In R. S. Patterson \& D. A. Rutz [eds.], Biological control of muscoid flies. Entomol. Soc. Am. Misc. Pub. No. 61. Lanham, MD.

Morrison, F. B. 1961. Feeds and feeding, abridged. Morrison, Clinton, IA.

Parr, H.C.M. 1959. Studies on Stomoxys calcitrans (L.) in Uganda, East Africa. I. A method of rearing large numbers of Stomoxys calcitrans. Bull. Entomol. Res. 50: 165-169.

Pickens, L. G. \& K. J. Lorenzen. 1983. A new larval diet for Musca domestica (Diptera: Muscidae). J. Med. Entomol. 5: 572-573.

SAS Institute. 1985. SAS user's guide: statistics. SAS Institute, Cary, NC.

Wilkes, A., G. E. Bucher, J. W. MacB. Cameron \& A. S. West, Jr. 1948. Studies on the housefly (Musca domestica L.) I. The biology and large scale production of laboratory populations. Can. J. Res. Sect. D. Zool. Sci. 26: 8-25.

Received for publication 13 April 1992; accepted 15 July 1992. 